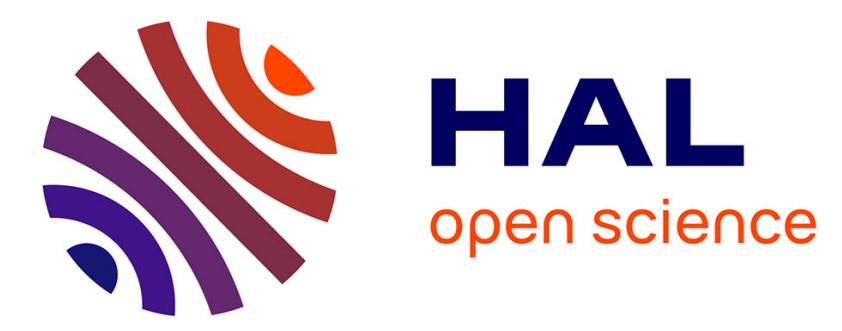

\title{
Variability in responsiveness to lovastatin of the primitive CD34 AML subfraction compared to normal CD34 cells
}

\author{
Susan D. P. W. M. Jonge-Peeters, Karen Weide, Folkert Kuipers, Wim J. \\ Sluiter, Elisabeth G. E. Vries, Edo Vellenga
}

\section{To cite this version:}

Susan D. P. W. M. Jonge-Peeters, Karen Weide, Folkert Kuipers, Wim J. Sluiter, Elisabeth G. E. Vries, et al.. Variability in responsiveness to lovastatin of the primitive CD34 AML subfraction compared to normal CD34 cells. Annals of Hematology, 2008, 88 (6), pp.573-580. 10.1007/s00277-008-0633-2 . hal-00477989

\section{HAL Id: hal-00477989 \\ https://hal.science/hal-00477989}

Submitted on 30 Apr 2010

HAL is a multi-disciplinary open access archive for the deposit and dissemination of scientific research documents, whether they are published or not. The documents may come from teaching and research institutions in France or abroad, or from public or private research centers.
L'archive ouverte pluridisciplinaire HAL, est destinée au dépôt et à la diffusion de documents scientifiques de niveau recherche, publiés ou non, émanant des établissements d'enseignement et de recherche français ou étrangers, des laboratoires publics ou privés. 


\title{
Variability in responsiveness to lovastatin of the primitive $\mathrm{CD34}^{+}$AML subfraction compared to normal $\mathrm{CD34}^{+}$cells
}

\author{
Susan D. P. W. M. de Jonge-Peeters • \\ Karen van der Weide $\cdot$ Folkert Kuipers • \\ Wim J. Sluiter • Elisabeth G. E. de Vries • Edo Vellenga
}

Received: 25 February 2008 /Accepted: 20 October 2008/Published online: 11 November 2008

(C) Springer-Verlag 2008

\begin{abstract}
In the present study, we questioned whether the cholesterol synthesis inhibitor lovastatin potentiates the cytotoxicity of chemotherapeutic agents in the primitive CD $34^{+}$subpopulation of acute myeloid leukemia (AML) cells. AML mononuclear cells $(n=17)$ were sorted in $\mathrm{CD}_{4} 4^{+}$and $\mathrm{CD}^{-} 4^{-}$fractions and compared to normal $\mathrm{CD} 4^{+-}$cells $(n=7)$. The percentage of surviving cells upon exposure to lovastatin $(25-100 \mu \mathrm{M})$ and/or chemotherapeutics (cytarabin or daunorubicin) was determined with a luminescent cell viability assay. The results demonstrate that the primitive $\mathrm{CD} 34^{+}$subpopulation of normal and AML cells displayed a higher sensitivity to
\end{abstract}

S. D. P. W. M. de Jonge-Peeters $\cdot$ K. van der Weide $\cdot$ E. Vellenga Department of Hematology, University of Groningen and University Medical Center Groningen,

P.O. Box 30.001, 9700 RB Groningen, The Netherlands

S. D. P. W. M. de Jonge-Peeters $\cdot$ K. van der Weide

E. G. E. de Vries

Department of Medical Oncology, University of Groningen and University Medical Center Groningen,

P.O. Box 30.001, 9700 RB Groningen, The Netherlands

\section{F. Kuipers}

Department of Pediatrics, University of Groningen and University

Medical Center Groningen,

P.O. Box 30.001, 9700 RB Groningen, The Netherlands

W. J. Sluiter

Department of Endocrinology, University of Groningen and University Medical Center Groningen,

P.O. Box 30.001, 9700 RB Groningen, The Netherlands

E. Vellenga $(\square)$

Department of Hematology,

University Medical Center Groningen,

Hanzeplein 1,

9713 GZ Groningen, The Netherlands

e-mail: e.vellenga@int.umcg.nl lovastatin than the more mature $\mathrm{CD} 34^{-}$subpopulation. The combination of lovastatin and chemotherapeutics resulted in a more pronounced inhibitory effect on both subpopulations. In contrast to the homogeneous results in normal $\mathrm{CD} 34^{+}$cells, a distinct heterogeneity in lovastatin sensitivity was found in AML samples. Therefore, a group of normal $(n=11)$ and abnormal $(n=6)$ responders were identified based on a reduced or increased cell survival compared to normal $\mathrm{CD} 34^{+}$cells. This distinction was not only observed in the $\mathrm{CD} 34^{+}$AML subfraction but also in $\mathrm{CD} 34^{+} \mathrm{CD} 38^{-} \mathrm{AML}$ cells. In the abnormal responder group, $50 \%$ of patients presented with unfavorable cytogenetics and significant higher peripheral blast cell counts, which coincided with poor treatment results. In summary, the findings indicate that the primitive subfraction of $\mathrm{CD} 34^{+}$AML cells is in the majority of cases affected by lovastatin treatment, which is potentiated when combined with chemotherapeutics. Heterogeneity of the response observed in AML patients allowed identification of a subgroup with poor prognosis.

Keywords AML · Cholesterol metabolism · Cytostatic agents $\cdot \mathrm{CD} 34$ subpopulations $\cdot \mathrm{ABC}$ transporters

\section{Introduction}

Acute myeloid leukemia (AML) is characterized by accumulation of immature myeloid cells in the bone marrow. These malignant cells are usually hierarchically structured, similar to the normal hematopoietic system. We have reported that, according to this hierarchal structure, ATP-binding cassette $(\mathrm{ABC})$ transporters are expressed in a differentiation-dependent manner [1]. Specifically, in primitive $\mathrm{CD} 34^{+} \mathrm{CD} 38^{-}$cells, a high expression of a number of $\mathrm{ABC}$ transporters genes was noticed in comparison to the 
more differentiated $\mathrm{CD} 34^{+} \mathrm{CD} 38^{+}$cells. Notably, in the leukemic counterpart, a much more heterogeneous pattern of $\mathrm{ABC}$ transporter gene expression was observed [1]. Recently, de Grouw et al. [2] published expression data for all 45 ABC transporters in AML cells. They found $22 \mathrm{ABC}$ transporters to be lower expressed in the $\mathrm{CD} 34^{+} \mathrm{CD} 38^{+}$ subpopulation compared to the $\mathrm{CD} 34^{+} \mathrm{CD} 38^{-}$subpopulation. In addition to the two major cholesterol efflux transporters (ABCA1 and ABCG1), two genes critical in cholesterol metabolism (3-hydroxy-3-methyl-glutaryl-CoA (HMGCoA) reductase and low-density lipoprotein receptor (LDLR)) were highly expressed in normal $\mathrm{CD} 34^{+} \mathrm{CD} 38^{-}$ cells, indicative for an active cholesterol metabolism $[1,3]$.

In AML cells, an aberrant cellular cholesterol metabolism has been demonstrated, including a higher LDLR activity [4]. Interestingly, it was recently shown in vitro that cells isolated from a subgroup of AML patients demonstrated in their leukemic cells "an acute cholesterol response", i.e., a rapid increase in cellular cholesterol content in response to cytotoxic agents [5]. These AML cells were further characterized by an increased chemosensitivity upon blocking this acute cholesterol response by pretreatment of cells with a statin [4]. Statins act as competitive inhibitors of the enzyme HMGCoA reductase and hence block cellular cholesterol synthesis. Consequently, a role for these cholesterol synthesis inhibitors to improve standard antileukemic treatment has been suggested [4, 6-10]. In the present study, we focused on a subpopulation of AML cells $\left(\mathrm{CD} 34^{+}\right)$, i.e., cells that have more in common with the more primitive leukemic progenitor/stem cell compartment [11], and questioned whether this subpopulation of cells is especially prone for the effects of lovastatin and chemotherapeutic agents. Our data demonstrate a higher sensitivity of the primitive CD34 ${ }^{+}$subpopulation for lovastatin compared to the more mature $\mathrm{CD} 34^{-}$subpopulation of normal as well as AML cells. Heterogeneity of the response observed in AML patients allowed identification of a subgroup with poor prognosis.

\section{Materials and methods}

\section{Normal CD34 ${ }^{+/-}$hematopoietic cells}

Normal mobilized peripheral blood cells were collected either from healthy donors or from patients awaiting autologous stem cell transplantation, undergoing granulocyte colony-stimulating factor (G-CSF) treatment, in accordance with institutional guidelines. $\mathrm{CD} 34^{+}, \mathrm{CD} 34^{-} 14^{+} 15^{+}$ $\left(\mathrm{CD} 34^{-}\right), \mathrm{CD} 34^{+} \mathrm{CD} 38^{-}$, and $\mathrm{CD} 34^{+} \mathrm{CD} 38^{+}$cells were obtained by means of the MoFlo flow cytometer (Dako Colorado Inc., Fort Collins, CO, USA).

\section{Patients}

After informed consent, bone marrow or peripheral blood cells were collected of AML patients at diagnosis. The Human Subject Review Board of the University Medical Center Groningen (The Netherlands) approved the protocol. Patients were classified according to the WHO classification [12]. Mononuclear cells were enriched by FicollIsopaque (Nycomed, Oslo, Norway) density gradient centrifugation and cryopreserved in RPMI 1640 medium (BioWhittaker, Brussels, Belgium) supplemented with 20\% fetal calf serum (FCS; Hyclone, Logan, UT, USA) and 20\% dimethyl sulfoxide (Merck, Amsterdam, The Netherlands) and stored at $-196^{\circ} \mathrm{C}$ as described [13].

\section{Materials}

Mevinolin (L-154, 803-00G17) in the lactone form was obtained from Merck, Sharp \& Dohme Research Laboratories (Rahway, NJ, USA), converted to its sodium salt, and a stock solution of mevinolin (lovastatin) at a concentration of $4 \mathrm{mg} / \mathrm{mL}$ was prepared as previously described. The cytotoxic agents daunorubicin (Aventis Pharma BV, Hoevelaken, The Netherlands) and cytarabin (Mayne Pharma (Benelux) SA-NV, Brussels, Belgium) were used.

\section{Flow cytometric sorting}

The normal and AML samples were incubated with a fluorescein isothiocyanate-conjugated antibody against CD34 (Becton Dickinson, San Jose, CA, USA) and a phycoerytrin-conjugated antibody against CD14 and CD15 or CD38. Sorting was performed using a MoFlo flow cytometer. Erythrocytes and dead cells were excluded from analysis by gating on forward and sideward light scatter. For RNA extraction, at least $3 \times 10^{4} \mathrm{CD} 34^{+}$and $3 \times 10^{4}$ $\mathrm{CD} 34^{-} \mathrm{CD} 14^{+} \mathrm{CD} 15^{+}$cells were sorted. No difference existed in average CD34 expression between normal and leukemic cells mean fluorescence intensity.

Luminescent cell viability assay and TaqMan PCR

This assay was used for determining the number of viable cells in culture based on quantitation of the ATP present, which signals the presence of metabolically active cells. The amount of ATP is directly proportional to the number of cells present in the culture. The ATP measurement was carried out according to the manufacturer's instructions using the Cell Titer-Glo ${ }^{\circledR}$ Luminescent cell viability assay (Promega, Madison, WI, USA). We prepared 96-well plates with $100 \mu \mathrm{L}$ RPMI 1640 medium supplemented with $10 \%$ FCS and sorted by the MoFlo flow cytometer, either $10^{4}$ $\mathrm{CD} 34^{+}$cells or $\mathrm{CD} 34^{-} \mathrm{CD} 14^{+} \mathrm{CD} 15^{+}$cells per well. The 
wells were incubated with different concentrations of lovastatin $(25,50$, and $100 \mu \mathrm{M})$ with and without different concentrations of either daunorubicin (0.01-0.5 $\mu \mathrm{M})$ or cytarabin $(0.0001-0.1 \mathrm{mg} / \mathrm{mL})$ and analyzed after $20 \mathrm{~h}$. All experiments were performed in duplicate. No difference existed in baseline average and median ATP levels between CD $34^{+}$and $\mathrm{CD}^{-} 4^{-}$cells. RNA extraction, cDNA synthesis, and quantitative polymerase chain reaction were performed as described before [13].

\section{Colony-forming cell assay}

$10^{3}$ normal or AML CD34 ${ }^{+}$cells were sorted into Iscove's Modified Dulbecco's Media (IMDM) containing 10\% FCS, $20 \mathrm{ng} / \mathrm{mL}$ interleukin-3 (IL-3), $100 \mathrm{ng} / \mathrm{mL}$ c-Kit ligand, $100 \mathrm{ng} / \mathrm{mL}$ Flt-3 ligand, and $100 \mathrm{ng} / \mathrm{mL}$ thrombopoietin as described. Twenty-four hours after treatment with different concentrations lovastatin, cytarabin, and daunorubicin, cells were plated into MethoCult H4230 (StemCell Technologies, Vancouver, Canada) supplemented with 20\% IMDM, $20 \mathrm{ng} / \mathrm{mL}$ IL-3, $20 \mathrm{ng} / \mathrm{mL}$ GCSF, $20 \mathrm{ng} / \mathrm{mL}$ IL-6, $20 \mathrm{ng} / \mathrm{mL}$ cKit ligand, and $1 \mathrm{U} / \mathrm{mL}$ EPO (Cilag: Eprex, Brussels, Belgium).

\section{Statistical analysis}

Friedman's and Mann-Whitney's nonparametric tests were performed to calculate significant differences, $p$ values of $<0.05$. SPSS 14.0 statistical software [14] was used to analyze the data. Additionally, we looked for additive and synergistic effects of the combination treatment of lovastatin and chemotherapeutics. Additivity was defined as an increased inhibitory effect on cell survival of the combination exposure compared to the single exposure of lovastatin or chemotherapeutics. Synergism was defined by two individual agents (lovastatin and chemotherapeutics) acting together and creating an inhibitory effect on cell survival greater than predicted by knowing only the separate inhibitory effects of the individual agents.

\section{Results}

Patient characteristics

The AML patients $(n=17)$ studied, median age of 51 (range 19-79), were classified according to the WHO classification: AML with cytogenetic abnormalities $(n=5)$, AML with prior dysplastic syndrome $(n=2)$, and the additional group consisting of M1 $(n=4)$, M2 $(n=3)$, and M4/M5 $(n=3)$. The clinical and cellular characteristics of the patients are shown in Table 1. The median peripheral blast cell count at diagnosis was $48.6 \times 10^{9} / \mathrm{L}$ (range $2.2-200$ ). The majority of the patients were treated according to ongoing HaematoOncology Co-operative Group (HOVON) protocols, i.e., the HOVON Swiss Group for Clinical Cancer Research AML42 study for patients $<60$ years [15] and the HOVON 43 study for patients $>60$ years [16]. Palliative treatment was given to patients that were ineligible for intensive chemotherapy $(n=2)$. These patients were treated with 6-mercaptopurine [17]. Eleven patients reached complete remission (CR) on protocol. In six patients, $\mathrm{CR}$ was not attained due to progression $(n=2)$ or to treatment related toxicity $(n=4)$. The median event-free survival (EFS) of all patients attaining CR was 13 months (range 1-37).

The $\mathrm{CD}_{3} 4^{+}$subpopulation of normal and AML hematopoietic cells is more sensitive to lovastatin treatment than the more mature $\mathrm{CD} 34^{-}$subpopulation

To evaluate whether differences exist in statin sensitivity between primitive and more differentiated cells, normal $\mathrm{CD}^{+} 4^{+}$and $\mathrm{CD}^{-} 14^{+} 15^{+}$subfractions $(n=7)$ were sorted from the mononuclear cell fraction from normal peripheral blood stem cells. A clear discrepancy between both fractions was observed upon lovastatin exposure. The CD $34^{+}$subpopulation demonstrated a reduction of cellular ATP to $64 \%$ at a dose of $50 \mu \mathrm{M}$ lovastatin compared to $123 \%$ in the $\mathrm{CD}^{-} 4^{-}$fraction $(p=0.008$; Fig. 1a).

A similar experimental setup was used for the AMLs $(n=17)$. From the total AML cell fraction, the CD $34^{+}$ subfraction was separated from the $\mathrm{CD} 34^{-}$fraction by MoFlo. The percentage of $\mathrm{CD}_{3} 4^{+}$cells varied strongly between the different AML samples as depicted in Table 1 (median 41\% (range 7-92\%)). Subsequently, the CD $34^{+}$ and $\mathrm{CD} 34^{-}$fractions were exposed to varying concentrations of lovastatin $(25-100 \mu \mathrm{M})$ for $20 \mathrm{~h}$ and the effects on cell survival were assessed. As depicted in Fig. 1b, a significant difference in sensitivity for lovastatin was observed for the $\mathrm{AML} \mathrm{CD} 34^{+}$versus $\mathrm{CD} 34^{-}$fraction. At $50 \mu \mathrm{M}$, a median reduction of $30 \%$ in survival (range minus 24-54) was observed for the $\mathrm{CD} 34^{+}$cells compared to $12 \%$ (range minus $51-42$ ) in the $\mathrm{CD} 34^{-}$fraction $(p=$ $0.029)$. A similar pattern was also observed at $100 \mu \mathrm{M}$ (43\% versus $23 \%, p=0.029$ ). Subsequently, we compared the AML subpopulations with the normal $\mathrm{CD}^{+} 4^{+}$and CD34 ${ }^{-}$cell fractions and observed a significant increased lovastatin sensitivity of the AML CD34 $4^{-}$fraction compared to the normal the $\mathrm{CD}^{-} 4^{-}$subpopulations $(p=0.005$; Fig. 1). This was not noticed for the AML and normal $\mathrm{CD}^{+} 4^{+}$cell fractions $(p=0.095)$. Based on the pattern of lovastatin sensitivity of the normal CD34 ${ }^{+}$cells, two subgroups within the AMLs could be distinguished. Eleven AML CD34 $4^{+}$samples had a response pattern comparable to normal CD34 ${ }^{+}$cells, whereas six showed a reduced lovastatin sensitivity (Fig. 3a; Table 1). A 
Table 1 Clinical and cellular characteristics of AML patients

\begin{tabular}{|c|c|c|c|c|c|c|c|c|c|c|c|}
\hline AMLs & $\begin{array}{l}\text { Age } \\
\text { (years) }\end{array}$ & $\begin{array}{l}\text { Leucocytes } \\
\text { presentation } \\
\left(\times 10^{9} / \mathrm{L}\right)\end{array}$ & $\begin{array}{l}\text { FAB } \\
\text { class }\end{array}$ & Cytogenetics & $\begin{array}{l}\text { Treatment } \\
\text { (it/pt) }\end{array}$ & Response & $\begin{array}{l}\mathrm{EFS}^{\mathrm{a}} \\
\text { (months) }\end{array}$ & OS & $\begin{array}{l}\% \mathrm{CD} 34^{+} \text {in } \\
\mathrm{AML} \\
\text { mononuclear } \\
\text { cell fraction }\end{array}$ & $\begin{array}{l}(\mathrm{Ab}) \text { normal } \\
\text { responder } \\
\text { to lovastatin } \\
\text { in } \mathrm{CD} 34^{+} \text {cells }\end{array}$ & $\begin{array}{l}\text { Risk-group } \\
\text { stratification }\end{array}$ \\
\hline
\end{tabular}

\begin{tabular}{|c|c|c|c|c|c|c|c|c|c|c|c|}
\hline 1 & 59 & 128 & M1 & $\mathrm{N}$ & it & $\mathrm{CR}$ & 18 & 1 & 24 & $\mathrm{~N}$ & Intermediate \\
\hline 2 & 68 & 4 & M5b & $\mathrm{N}$ & it & $\mathrm{CR}$ & 15 & 0 & 64 & $\mathrm{~N}$ & Intermediate \\
\hline 3 & 51 & 33 & M1 & $\mathrm{N}$ & it & $\mathrm{CR}$ & 37 & 1 & 63 & $\mathrm{~N}$ & Intermediate \\
\hline 4 & 73 & 6 & M2 & $\mathrm{N}$ & it & $\mathrm{CR}$ & 12 & 1 & 28 & $\mathrm{~N}$ & Intermediate \\
\hline 5 & 79 & 96 & M5b & $\mathrm{N}$ & $\mathrm{pt}$ & NR & - & 0 & 15 & $\mathrm{~N}$ & Intermediate \\
\hline 6 & 19 & 10 & M2 & $\mathrm{N}$ & it & $\mathrm{CR}$ & 13 & 1 & 23 & $\mathrm{~N}$ & Intermediate \\
\hline 7 & 43 & 24 & M5 & $\mathrm{N}$ & it & $\mathrm{CR}$ & 1 & 0 & 28 & $\mathrm{~N}$ & Intermediate \\
\hline 8 & 64 & 11 & M5 & inv. 16 & it & $\mathrm{CR}$ & 8 & 1 & 20 & $\mathrm{~N}$ & Good \\
\hline 9 & 48 & 16 & M1 & $\mathrm{N}$ & it & $\mathrm{CR}$ & 8 & 0 & 17 & $\mathrm{~N}$ & Intermediate \\
\hline 10 & 49 & 50 & M4/M5 & $\mathrm{N}$ & it & $\mathrm{CR}$ & 2.5 & 0 & 7 & $\mathrm{~N}$ & Intermediate \\
\hline 11 & 55 & 2 & M2 & $\mathrm{N}$ & it & $\mathrm{CR}$ & 15 & 0 & 56 & $\mathrm{~N}$ & Intermediate \\
\hline 12 & 44 & 66 & M5 & $3 q-, 5 q-,+8$ & it & $\mathrm{NE}^{\text {tox }}$ & 0 & 0 & 8 & A & Poor \\
\hline 13 & 54 & 48 & M5a & $\mathrm{N}$ & it & $N E^{\text {tox }}$ & 0 & 0 & 85 & A & Intermediate \\
\hline 14 & 67 & 63 & M1 & $\mathrm{T}(6 ; 9)$, Trisomy 13 & it & NR & 0 & 0 & 35 & A & Poor \\
\hline 15 & 19 & 102 & M5 & inv. 16 & it & $\mathrm{CR}$ & $21+$ & 1 & 60 & A & Intermediate \\
\hline 16 & 42 & 200 & M1 & inv. $3 q,-7,-10$ & it & NR & 0 & 0 & 87 & $\mathrm{~A}$ & Poor \\
\hline 17 & 38 & 96 & M1 & $\mathrm{N}$ & $\mathrm{pt}$ & NR & - & 0 & 92 & A & Intermediate \\
\hline
\end{tabular}

$N$ normal, inv. inversion, it intensive treatment, $p t$ palliative treatment, $C R$ complete remission, $N R$ nonresponder, $N E$ not evaluable due to treatment related toxicity, EFS event-free survival, $O S$ overall survival, 0 death, 1 alive, $N$ normal responders (defined as AML CD34 ${ }^{+}$cells demonstrating a similar effect on cell survival as normal CD34 $4^{+}$cells), $A$ abnormal responders (defined as AML CD34 ${ }^{+}$showing a dissimilar effect on cell survival to normal $\mathrm{CD} 34^{+}$cells)

${ }^{a}$ For event-free survival, a plus following the value indicates still no relapse as at September 12, 2007

${ }^{\mathrm{b}}$ Risk group stratification is based on (un)favorable cytogenetics combined with peripheral blood blast cell counts

comparable pattern was observed for the AML CD34fraction (Fig. 3b).

The combination of lovastatin and chemotherapeutics potentiates cell death

To evaluate whether the cytotoxic effects of two frequently used cytostatic agents, cytarabin and daunorubicin, might be promoted by cotreatment with lovastatin, the AML CD34 ${ }^{+}$ and $\mathrm{CD} 34^{-}$subfractions were incubated with varying concentrations of lovastatin $(25,50$, and $100 \mu \mathrm{M})$ in the presence or absence of varying concentrations of daunorubicin $(0.01-0.5 \mu \mathrm{M})$ or cytarabin $(0.0001-0.1 \mathrm{mg} / \mathrm{mL})$ for $24 \mathrm{~h}$. A dose-dependent decrease in cell survival was seen as depicted in Fig. 2, which was augmented by lovastatin treatment. A median survival reduction of $21 \%$ (range minus 28-64\%) was accomplished by exposing the AML CD34 ${ }^{+}$cells to $0.1 \mu \mathrm{M}$ daunorubicin, which was $43 \%$ (range minus $56-78 \%$ ) when the $\mathrm{CD} 34^{+}$AML cells were exposed to the combination of daunorubicin and $25 \mu \mathrm{M}$ lovastatin (Fig. 2a).

The combined use was slightly more effective in the $\mathrm{CD} 34^{+}$subpopulation compared to the $\mathrm{CD} 34^{-}$subpopulation (Fig. $2 b$; median $43 \%$ versus $36 \%$ ) but the difference did not reach statistical significance. Comparable results were obtained for cytarabin (data not shown). However, also here within the group of AMLs, different subgroups could be distinguished when looking at cell survival. Most AML CD34 ${ }^{+}$cells with a reduced statin sensitivity demonstrated also a diminished susceptibility for the combined use of statins plus cytarabin or daunorubicin (Fig. 3). To investigate whether the observed effects were also noticed in the most primitive AML cell population, AML CD34 ${ }^{+}$cells were sorted into the $\mathrm{CD} 34^{+} \mathrm{CD} 38^{-}$cell fraction and the $\mathrm{CD} 34^{+} \mathrm{CD} 38^{+}$fraction $(n=7)$. Four AML samples belonged to the normal responder group and three samples to the abnormal responder group. As depicted in Fig. 4, the same distinction in responsiveness to cytostatic agents was observed in the absence or presence of lovastatin. Especially in the $\mathrm{CD} 34^{+} \mathrm{CD} 38^{-}$subfraction, the discrepancy between normal versus abnormal responders was most noticeable (e.g., for ARA-C in combination with $25 \mu \mathrm{M}$ lovastatin, $p=0.01$ for $\mathrm{CD} 34^{+} \mathrm{CD} 38^{-}$versus $p=0.2$ for $\mathrm{CD} 34^{+} \mathrm{CD} 38^{+}$; for DNR, $p=0.05$ versus $p=0.5$ ).

To verify whether similar results can be obtained in a clonogenic assay, normal and AML $\mathrm{CD} 34^{+}$cells were exposed to lovastatin and/or cytostatic agents for $24 \mathrm{~h}$ and subsequently cultured in CFC medium. However, CD $34^{+}$ 


\section{A Normal CD34 and CD34 cells}

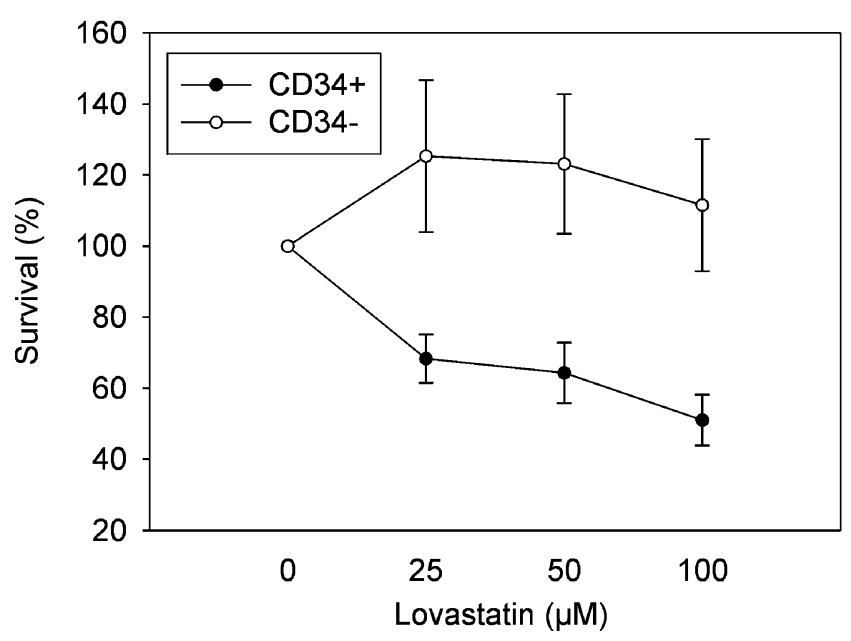

\section{B CD34 and CD34 AML cells}

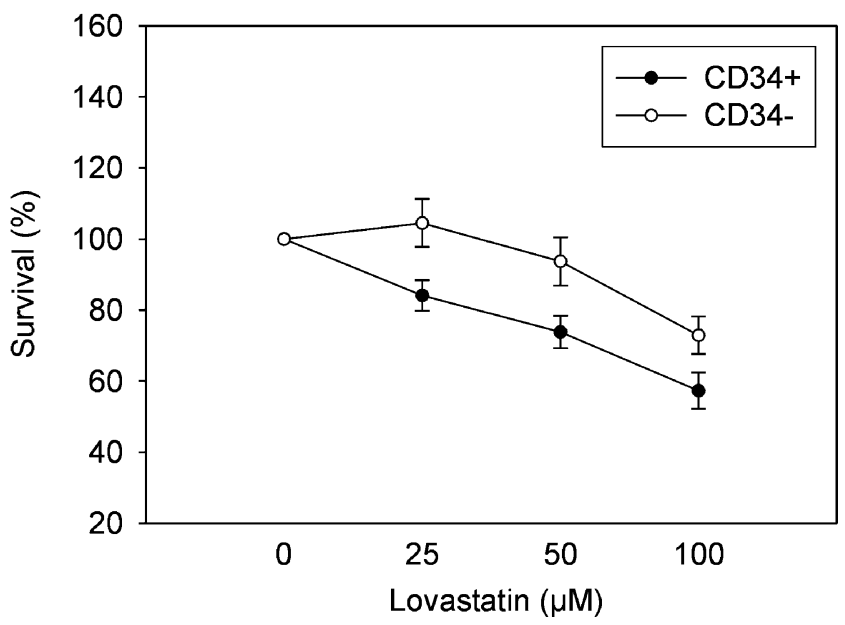

Fig. 1 Cell survival of $\mathrm{CD} 34^{+}$and $\mathrm{CD} 34^{-}$normal $(\mathbf{a} ; n=7)$ and $\mathrm{AML}$ cells $(\mathbf{b} ; n=17)$ upon incubation with increasing lovastatin concentrations $(25-100 \mu \mathrm{M})$. SEM are indicated

cells from six out of seven AML samples did not show any in vitro colony formation in the CFC assay. Normal CD34 $4^{+}$ cells $(n=5)$ showed an inhibition of $12 \%$ and $8 \%$ with $25 \mu \mathrm{M}$ lovastatin or daunorubicin, respectively, which increased to $36 \%$ inhibition when both agents were used $(p=0.01$, data not shown). Comparable results were obtained cytarabin $(28 \%$ versus $60 \%, p=0.04)$.

Given the observed variability in effects of lovastatin on the CD34 $4^{+}$AML cells, we questioned whether this might be explained by a difference in expression or modulation of downstream targets. Therefore, the ABCG1 and ABCA1 mRNA expression levels were studied both in the normal responder and abnormal responder AML group and compared to normal $\mathrm{CD} 34^{+}$cells. A nonsignificant higher ABCG1 mRNA expression was observed in the normal responder AML group compared to the abnormal responder AML group and normal $\mathrm{CD} 34^{+}$cells. In addition, the lovastatin-induced ABCG1 mRNA expression was studied in the different groups. No statistically significant difference was found between normal CD $34^{+}$cells $(0.4$ fold downregulation, range $0.29-0.36$ ) versus the normal and abnormal AML responder group, 0.2 (range minus $0.16-0.53$ ), and 0.5 fold (range 0.16-0.70) downregulation, respectively.

In vitro response pattern and clinical outcome

In view of the observed in vitro difference for statin sensitivity, we questioned whether these findings might correspond to patient characteristics or patient outcome. In the AML responder group, a normal or favorable cytogenetic pattern was found in $100 \%$ of the patients, while in the abnormal responder group, an unfavorable cytogenetic
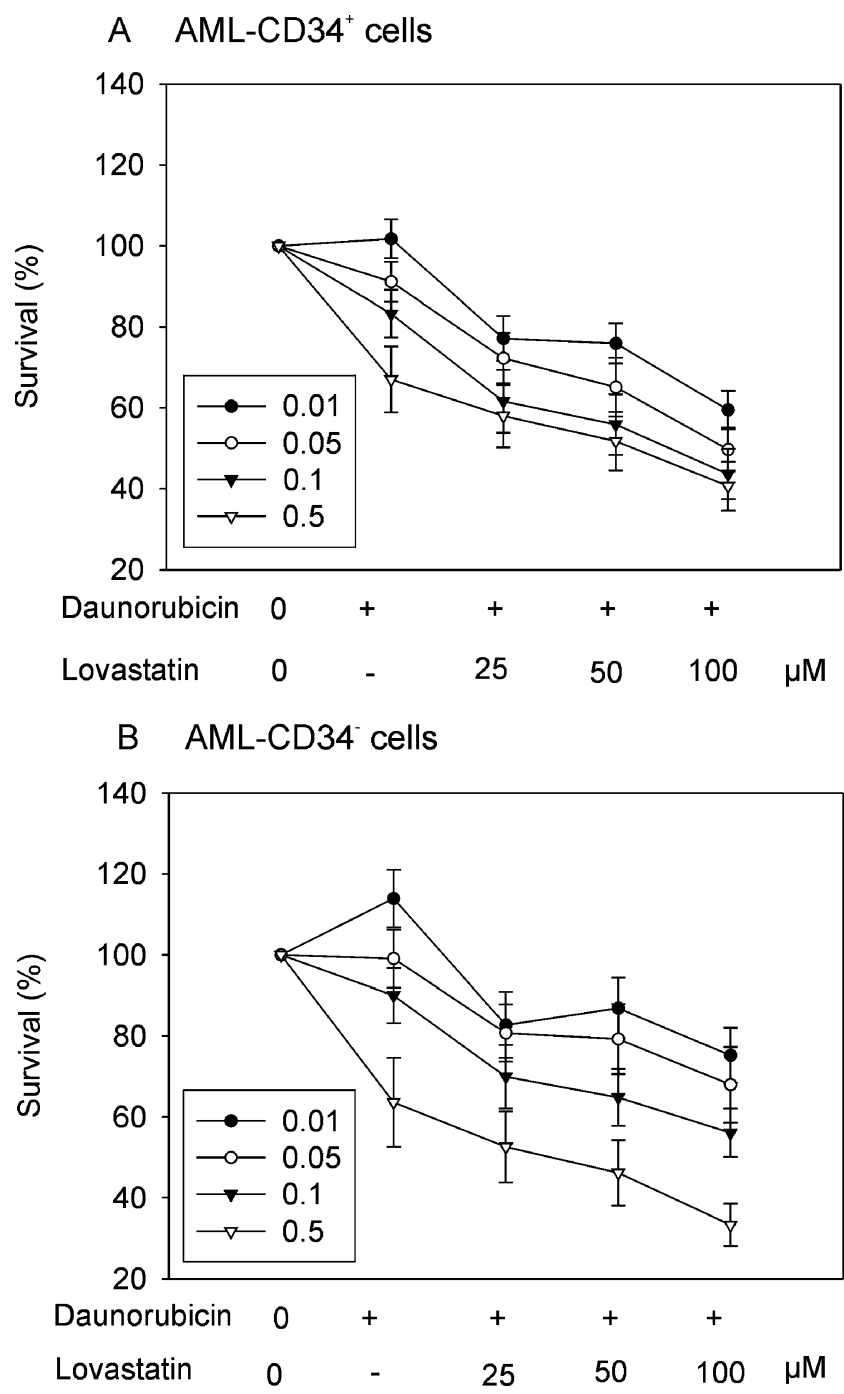

Fig. 2 Effects of increasing concentrations of chemotherapeutic drugs on in vitro survival of subpopulations of AML cells. CD34 $4^{+}$(a) and CD34 ${ }^{-}$(b) AML cells of all patients $(n=17)$ were incubated with lovastatin in combination with variable concentrations of daunorubicin $(0.01-0.5 \mu \mathrm{M})$. SEM are indicated 
Fig. 3 Effects of increasing concentrations of lovastatin in combination with chemotherapeutic drugs on in vitro survival of $\mathrm{CD} 34^{+}(\mathbf{a}-\mathbf{c})$ and $\mathrm{CD} 34^{-}(\mathbf{d}-$ f) normal and AML cells. Three groups are demonstrated in $\mathbf{a}-\mathbf{f}$. Two AML patient groups (normal responders $(n=13)$ and abnormal responders $(n=4)$; in total, $n=17$ ) and a normal $\mathrm{CD}^{++/-}$group $(n=7)$ are shown. SEM are indicated
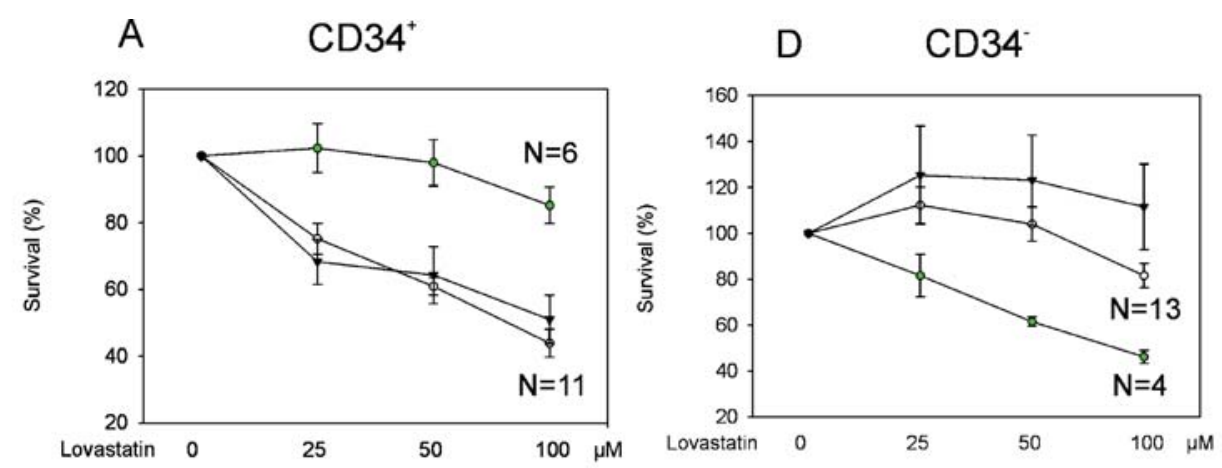

E
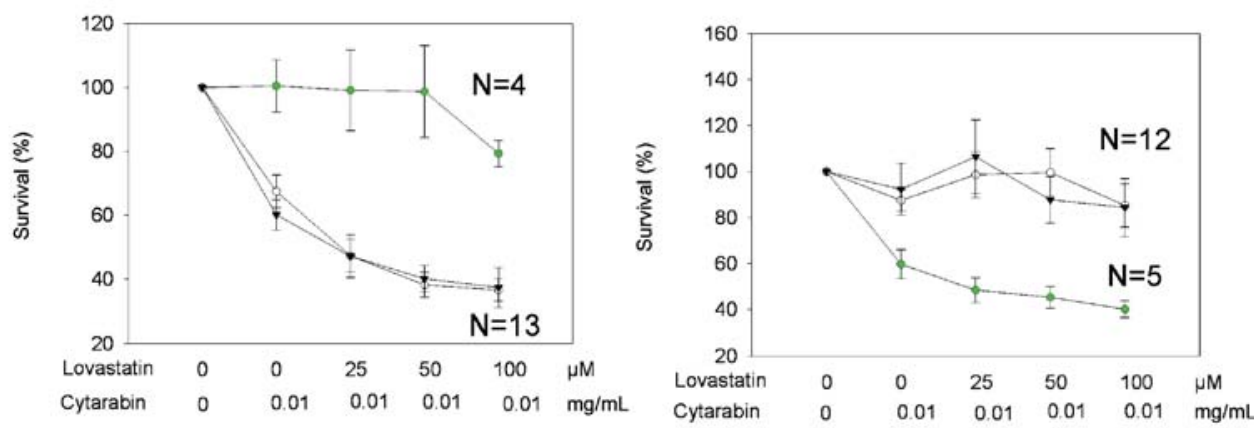

C

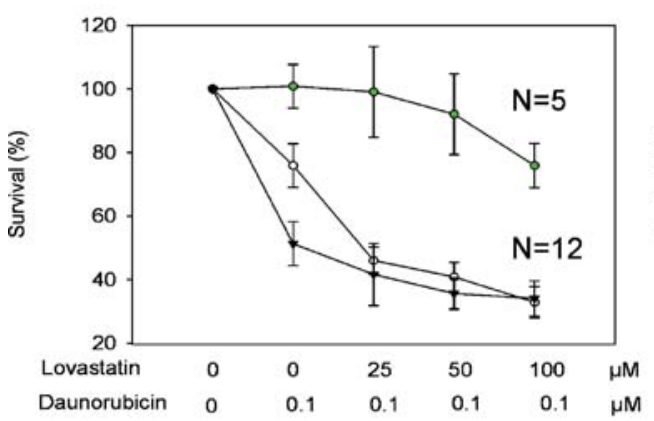

pattern was present in $50 \%$ of the patients. In the responder group, the median peripheral blast cell count at presentation was $16.6 \times 10^{9} / \mathrm{L}$ (range $2.2-128.3$ ) and in the abnormal responder group was $81.4 \times 10^{9} / \mathrm{L}$ (range $48.6-200, p=$ 0.02 ). Based on these factors, three prognostic risk groups can be defined, i.e., favorable risk (favorable cytogenetics in combination with a peripheral blood blast cell count $<20 \times 10^{9} / \mathrm{L}$ at diagnosis), poor risk (those with poor-risk cytogenetics), and intermediate risk group (all others) [18, 19]. In the responder group, $100 \%$ of the patients belonged to the good or intermediate risk group while in the abnormal responder group, this value was only $50 \%$ (Table 1). These findings correlated with treatment results. Complete remission on intensive chemotherapy was attained in $91 \%$ of the patients in the AML normal responder group with an EFS of 12.5 months (range 1$37)$. In the abnormal responders, CR was attained in $17 \%$ of the patients with a EFS of 0 month (range 0-15).

\section{Discussion}

In the present study, we analyzed the in vitro effect of lovastatin on the survival of AML subpopulations in the absence or presence of conventional applied chemotherapeutics. So far, in vitro studies on statins in AML have been focused on the total AML cell population [6-9]. However, information of well-defined subpopulations 
Fig. 4 Effects of increasing concentrations of lovastatin in combination with chemotherapeutic drugs on in vitro survival of sorted $\mathrm{CD} 34^{+} \mathrm{CD} 38^{-}(\mathbf{a}, \mathbf{b})$ and $\mathrm{CD} 34^{+} \mathrm{CD} 38^{+}(\mathbf{c}, \mathbf{d}) \mathrm{AML}$ cells. Two groups are shown: normal responders $(n=4)$ and abnormal responders $(n=3)$. SEM are indicated

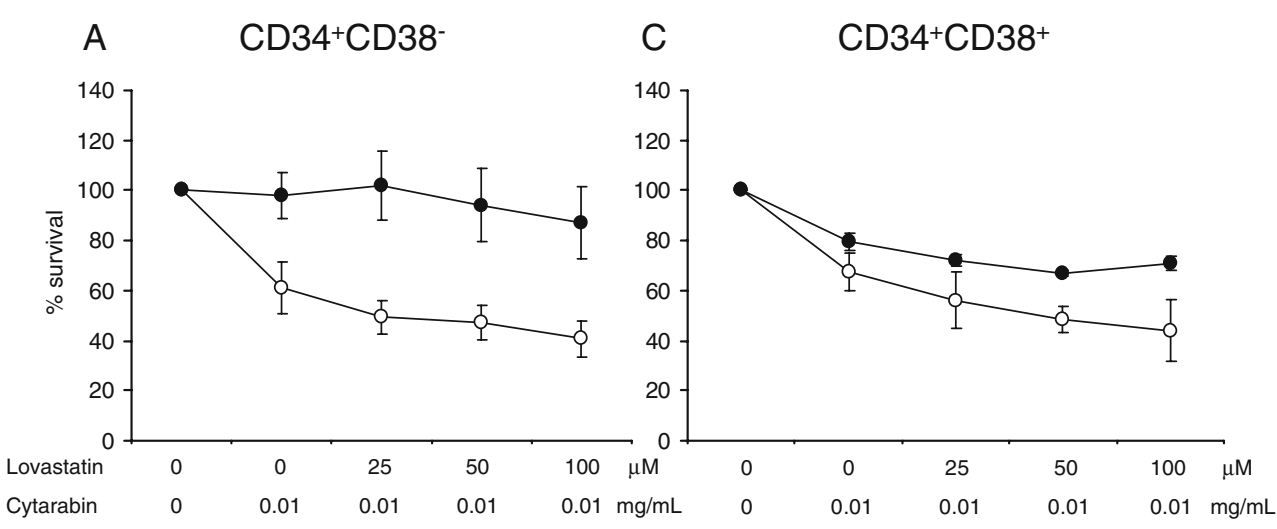

B
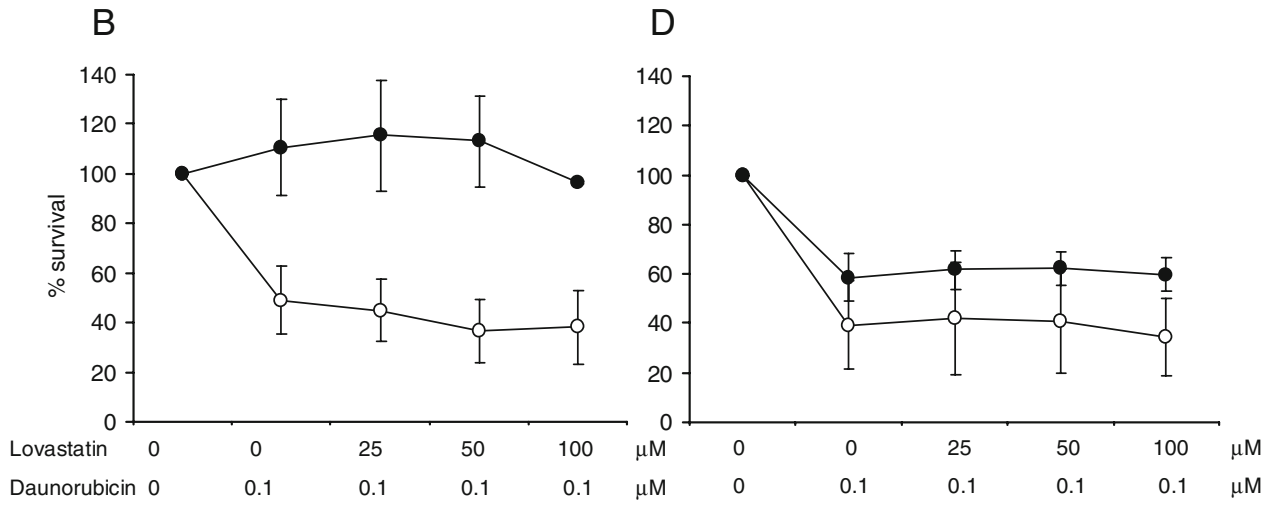

- - AML Normal Response

AML Abnormal Response

might provide additional information especially regarding the primitive $\mathrm{CD} 34^{+} \mathrm{AML}$ cells that are responsible for the ongoing in vivo propagation $[19,20]$. By studying two different subpopulations of AML cells (primitive CD34 ${ }^{+}$ cells and more mature $\mathrm{CD} 34^{-}$cells), we were able to demonstrate a significant difference in lovastatin susceptibility. The inhibitory effects of lovastatin were especially observed on the primitive $\mathrm{CD} 34^{+}$subpopulation. The effects on the more mature $\mathrm{CD} 34^{-}$subpopulation were less pronounced, suggesting that the primitive cell fraction is more dependent on cholesterol synthesis, which is in line with the high expression of $\mathrm{ABC}$ transporters in these cells. In addition, there were increased although variable inhibitory effects by the combined use of lovastatin and cytotoxic agents in both the AML and normal $\mathrm{CD} 34^{+}$cells. Interestingly, we found that some AML CD $34^{+}$cells followed a response pattern similar to normal $\mathrm{CD} 34^{+}$cells while $35 \%$ of the AML CD $34^{+}$cells showed no change. This could not be reversed in a number of cases by co-exposure the cells to chemotherapeutic agents. Interestingly, the distinction between normal and abnormal responders for the AML CD $34^{+}$fraction was most pronounced in the $\mathrm{CD} 34^{+} \mathrm{CD} 38^{-}$ cell fraction, a population that is enriched for leukemic stem cells [21]. The difference in responsiveness between the normal- and abnormal-responder AML groups could not be explained by a difference in the percentage of AML CD34 cells. In addition, no difference in susceptibility for lovastatin-mediated upregulation of ABCG1 mRNA was observed which is a major downstream target of lovastatin. It is more conceivable that the difference is linked to additional cellular characteristics of the AML cells belonging to both groups. Patient characteristics demonstrated that the abnormal responder group had a significant higher peripheral blast cell count at presentation. Moreover, the group was characterized by a high frequency of poor-risk cytogenetic abnormalities. The cause of the difference in susceptibility is not resolved but might be linked to differences in the farnesylation or geranylgeranylation pathways that are also affected by lovastatin $[3,6]$. It has been demonstrated that statins disrupt the localization and function of isoprenylated molecules in the cell membrane $[3,6]$. This change will result in an altered GTPase function of the Ras or Rho signaling that has an important impact on cellular processes such as proliferation and survival [22, 23]. Alternatively, the difference may be linked to an altered expression of anti-apoptotic proteins between both AML groups. It has been described that overexpression of Bcl-xL protects against statin-induced apoptosis in murine 
tubular cells [24]. Both of these possible explanations are currently under evaluation.

In summary, these results demonstrate distinct differences in lovastatin susceptibility between $\mathrm{CD} 4^{+}$and $\mathrm{CD}_{3}{ }^{-}$in the normal and leukemic counterpart and between different AML subtypes. Additional studies will clarify whether the described in vitro assay can be used for in vivo identification of patients that might benefit from application of statins in combination with chemotherapeutic agents.

Acknowledgments We thank A.T.J. Wierenga for his help with the cell viability assay. This work was supported by a grant of the Dutch Cancer Society (RUG 2006-3580).

\section{References}

1. Peeters SD, van der Kolk DM, de Haan G, Bystrykh L, Kuipers F, de Vries EG et al (2006) Selective expression of cholesterol metabolism genes in normal CD34+CD38- cells with a heterogeneous expression pattern in AML cells. Exp Hematol 34:622630 doi:10.1016/j.exphem.2006.01.020

2. de Grouw EP, Raaijmakers MH, Boezeman JB, van der Reijden BA, van de Locht LT, de Witte TJ et al (2006) Preferential expression of a high number of ATP binding cassette transporters in both normal and leukemic CD34+. Leukemia 20:750-754 doi:10.1038/sj.leu.2404131

3. Wong J, Quinn CM, Brown AJ (2004) Statins inhibit synthesis of an oxysterol ligand for the liver $\mathrm{x}$ receptor in human macrophages with consequences for cholesterol flux. Arterioscler Thromb Vasc Biol 24:2365-2371 doi:10.1161/01.ATV.0000148707.93054.7d

4. Li HY, Appelbaum FR, Willman CL, Zager RA, Banker DE (2003) Cholesterol-modulating agents kill acute myeloid leukemia cells and sensitize them to therapeutics by blocking adaptive cholesterol responses. Blood 101:3628-3634 doi:10.1182/blood2002-07-2283

5. Banker DE, Mayer SJ, Li HY, Willman CL, Appelbaum FR, Zager RA (2004) Cholesterol synthesis and import contribute to protective cholesterol increments in acute myeloid leukemia cells. Blood 104:1816-1824 doi:10.1182/blood-2004-01-0395

6. Dimitroulakos J, Nohynek D, Backway KL, Hedley DW, Yeger H, Freedman MH et al (1999) Increased sensitivity of acute myeloid leukemias to lovastatin-induced apoptosis: a potential therapeutic approach. Blood 93:1308-1318

7. Wu J, Wong WW, Khosravi F, Minden MD, Penn LZ (2004) Blocking the Raf/MEK/ERK pathway sensitizes acute myelogenous leukemia cells to lovastatin-induced apoptosis. Cancer Res 64:6461-6468 doi:10.1158/0008-5472.CAN-04-0866

8. Minden MD, Dimitroulakos J, Nohynek D, Penn LZ (2001) Lovastatin induced control of blast cell growth in an elderly patient with acute myeloblastic leukemia. Leuk Lymphoma 40:659-662 doi:10.3109/10428190109097663

9. Stirewalt DL, Appelbaum FR, Willman CL, Zager RA, Banker DE (2003) Mevastatin can increase toxicity in primary AMLs exposed to standard therapeutic agents, but statin efficacy is not simply associated with ras hotspot mutations or overexpression. Leuk Res 27:133-145 doi:10.1016/S0145-2126(02)00085-1
10. Kornblau SM, Banker DE, Stirewalt D, Shen D, Lemker E, Verstovsek S et al (2007) Blockade of adaptive defensive changes in cholesterol uptake and synthesis in AML by the addition of pravastatin to idarubicin + high dose Ara-C: a phase 1 study. Blood 109:2999-3006

11. van Gosliga D, Schepers H, Rizo A, van der Kolk D, Vellenga E, Schuringa JJ (2007) Establishing long-term cultures with selfrenewing acute myeloid leukemia stem/progenitor cells. Exp Hematol 35:1538-1549 doi:10.1016/j.exphem.2007.07.001

12. Harris NL, Jaffe ES, Diebold J, Flandrin G, Muller-Hermelink HK, Vardiman J et al (1999) World Health Organization classification of neoplastic diseases of the hematopoietic and lymphoid tissues: report of the Clinical Advisory Committee meeting-Airlie House, Virginia, November 1997. J Clin Oncol 17:3835-3849

13. Schepers H, van Gosliga D, Wierenga AT, Eggen BJ, Schuringa JJ, Vellenga E (2007) STAT5 is required for long-term maintenance of normal and leukemic humanstem/progenitor cells. Blood 110:2880-2888 doi:10.1182/blood-2006-08-039073

14. SPSS for Windows, Rel. 14.0.0. 2005. Chicago: SPSS Inc.

15. Lowenberg B, Boogaerts MA, Daenen SM, Verhoef GE, Hagenbeek A, Vellenga E et al (1997) Value of different modalities of granulocyte-macrophage colony-stimulating factor applied during or after induction therapy of acute myeloid leukemia. J Clin Oncol 15:3496-3506

16. Ossenkoppele GJ, Graveland WJ, Sonneveld P, Daenen SM, Biesma DH, Verdonck LF et al (2004) The value of fludarabine in addition to ARA-C and G-CSF in the treatment of patients with high-risk myelodysplastic syndromes and AML in elderly patients. Blood 103:2908-2913 doi:10.1182/blood-2003-07-2195

17. Daenen SM, de Wolf JThM, Vellenga E, van Imhoff GW, van den Berg-de Ruiter E, Smit JW (2001) 6-Mercaptopurine, still valuable for the palliative treatment of acute myeloid leukemia. Hematol 6:231-40

18. Breems DA, Boogaerts MA, Dekker AW, van Putten WL, Sonneveld P, Huijgens PC et al (2005) Autologous bone marrow transplantation as consolidation therapy in the treatment of adult patients under 60 years with acute myeloid leukaemia in first complete remission: a prospective randomized Dutch-Belgian Haemato-Oncology Co-operative Group (HOVON) and Swiss Group for Clinical Cancer Research (SAKK) trial. Br J Haematol 128:59-65 doi:10.1111/j.1365-2141.2004.05282.x

19. Guan Y, Gerhard B, Hogge DE (2003) Detection, isolation, and stimulation of quiescent primitive leukemic progenitor cells from patients with acute myeloid leukemia (AML). Blood 101:31423149 doi:10.1182/blood-2002-10-3062

20. de Jonge-Peeters SD, Kuipers F, de Vries EG, Vellenga E (2007) $\mathrm{ABC}$ transporter expression in hematopoietic stem cells and the role in AML drug resistance. Crit Rev Oncol Hematol 62:214-226 doi:10.1016/j.critrevonc.2007.02.003

21. Bonnet D, Dick JE (1997) Human acute myeloid leukaemia is organized as a hierarchy that originates from a primitive hematopoietic cell. Nat Med 3:730-737 doi:10.1038/nm0797-730

22. Zhang FL, Casey PJ (1996) Protein prenylation: molecular mechanisms and functional consequences. Annu Rev Biochem 65:241-269 doi:10.1146/annurev.bi.65.070196.001325

23. Du W, Prendergast GC (1999) Geranylgeranylated RhoB mediates suppression of human tumor cell growth by farnesyltransferase inhibitors. Cancer Res 59:5492-5496

24. Blanco-Colio LM, Justo P, Daehn I, Lorz C, Ortiz A, Egido J (2003) Bcl-xL overexpression protects from apoptosis induced by HMG-CoA reductase inhibitors in murine tubular cells. Kidney Int 64:181-191 doi:10.1046/j.1523-1755.2003.00080.x 